\title{
RIYADH BIOREMEDIATION FACILITY Methods Document
}

August 2015

\section{Prepared by:}

Research Fellow: Jean Trottier, Assistant Professor, Department of Landscape Architecture, University of Manitoba

Research Assistant: Kevin Eidick, MLA Candidate, University of Manitoba

Firm Liaison: Drew Wensley, CEO, Moriyama \& Teshima Planners Ltd.

This Methods Document accompanies a Landscape Performance Series Case Study Brief. It was produced through the 2015 Landscape Architecture Foundation's Case Study Investigation (CSI) program, a unique research collaboration that matches LAF-funded faculty-student research teams with leading practitioners to document the benefits of exemplary high-performing landscape projects.

The full case study can be found at: https://landscapeperformance.org/case-study-briefs/riyadh-bioremediation-facility 


\section{Landscape Performance Benefits}

\section{Environmental benefits}

\section{General methodology}

Water quality data was obtained by Nelson Environmental Inc., a Canadian firm hired by the Arriyadh Development Authority to conduct the ongoing monitoring of the project's environmental performance. 4 on-site water quality experts are responsible for collecting data and monitoring outcomes.

The Bioremediation Sampling Monitoring Program is designed to allow for water sample collection at 4 strategic locations: at both the inlet and outlet of the bioremediation facility and at 2 intermediate locations between the 3 main cell groups. There are 22 water quality parameters being analyzed in each location, which are grouped under 4 principal categories: general variables, organics, nutrients, and microbiology. Samples are collected and analyzed monthly. See the water quality summary data for selected parameters in Figure 10, in appendix A.

The long-term purpose of the monitoring program is to compare system performance to the Wadi Hanifah Comprehensive Master Plan objectives and to develop long-term bioremediation operation and maintenance protocols. The facility demonstrated its efficiency within 1 year of operation, as can be seen in the 2009 chart in Figure 1. Results from continued monitoring between July 2009 and May 2015 are discussed in more detail below.

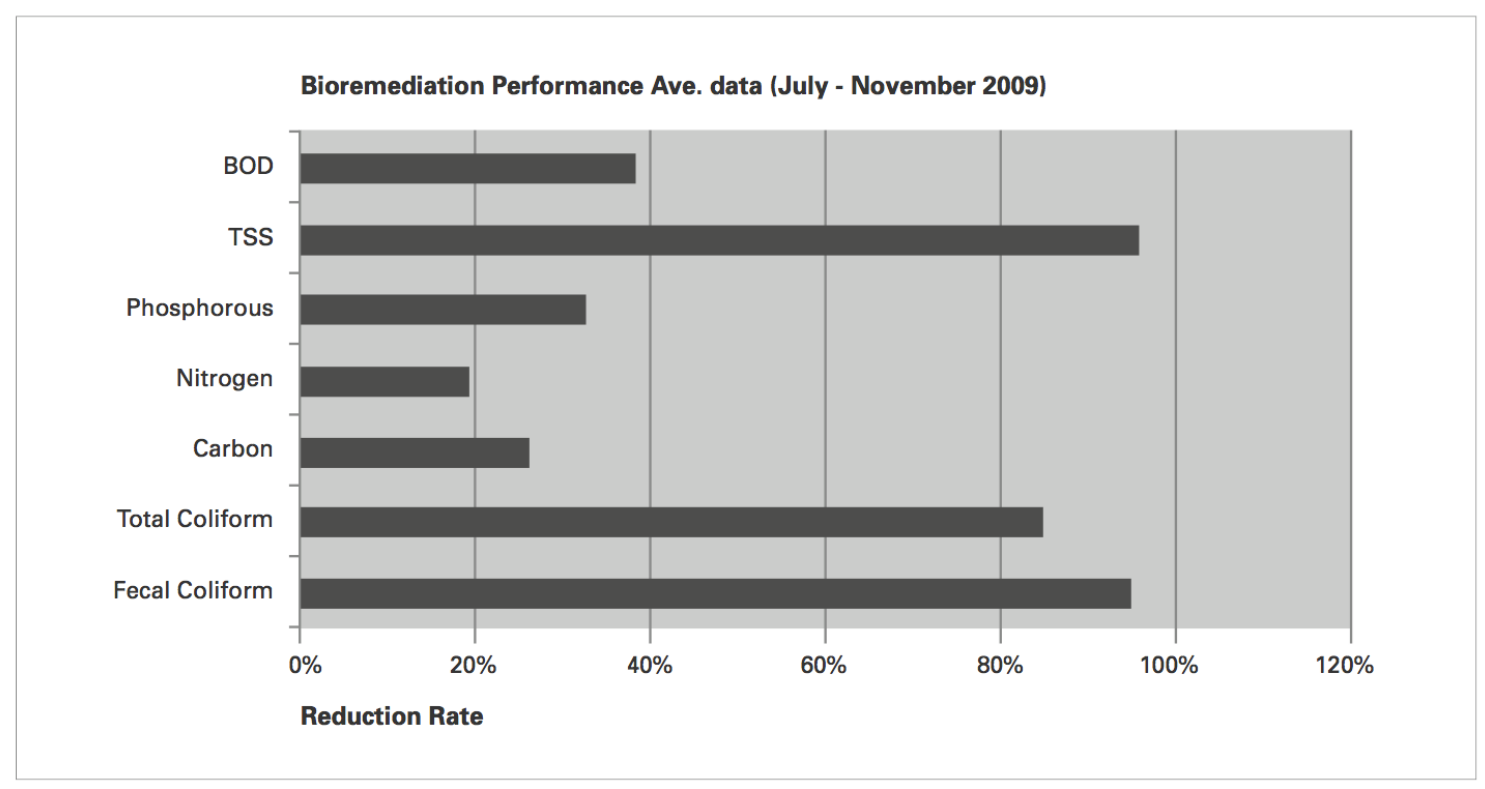

Figure 1. Reduction rate for key water quality parameters after the first year of operation, November 2009. Source: Moriyama \& Teshima Planners Inc. 2010. Wadi Hanifah Restoration Project. March 2010. Page 23. Based on data from Nelson Environmental Inc. 2010. Bioremediation and Surface Water Monitoring Report. February 2010. 


\section{General limitations}

Nelson Environmental Inc. was also hired to conduct pre-design water quality assessment and assist Moriyama \& Teshima Planners in the refinement and implementation of the bioremediation scheme. Nelson Environmental Inc. has been retained by the Arriyadh Development Authority since 2009 to monitor the post-construction performance of the facility. As such, no third party assessment of the facility's performance is currently available.

\section{- Treats an average of $\mathbf{9 2 . 5}$ million gallons of urban wastewater per day with a projected treatment capacity of 317 million gallons per day by 2025, the equivalent of more than 1.5 bathtubs per Riyadh resident each day.}

The first phase of the facility was designed for a maximum of 118.9 gallons per day. Low (summer) operating volumes average 66.0 million gallons per day. The operation annual average is established at 92.5 million gallons per day.

\section{Methodology}

Sources: Volumes taken from Moriyama \& Teshima Planners Inc. 2010. Wadi Hanifah Restoration Project. March 2010, page 11, and from interviews with the design firm.

- Removes an estimated $89 \%$ of fecal coliforms, $79 \%$ of total coliforms, $94 \%$ of total suspended solids, $33 \%$ of phosphorous, and $13.5 \%$ of nitrogen from urban wastewater, allowing for occasional human contact after it has been treated.

\section{Methodology}

The water quality data was obtained from Nelson Environmental Inc. See Figure 10 in appendix A for a sample.

The assessment of water quality for non-potable use relies of concentrations of coliforms (fecal and total), suspended solids, and dissolved oxygen.

Total post-processing fecal coliform concentrations fluctuate between 250.00 and 14,333.33 $\mathrm{CFU} / 100 \mathrm{~mL}$, with an average of $1,034.89 \mathrm{CFU} / 100 \mathrm{~mL}$. This last number takes into account abnormally high recorded concentrations at the inlet of 91,333 CFU/100 mL in July 2009 and about 160,000 CFU/100 mL in May 2015.

Total post-processing suspended solids concentrations vary from 1 to $4 \mathrm{mg} / \mathrm{L}$ with an average of 2 $\mathrm{mg} / \mathrm{L}$.

These concentrations meet some of the American Environmental Protection Agency standards for non-potable public water uses (in bold, below):

Fecal coliforms (CFU/mL)

- Body-contact recreation

- Beaches fewer than 200 colonies $/ 100 \mathrm{~mL}$ fewer than 235 colonies / $100 \mathrm{~mL}$ 
- Infrequent use full body contact

- Fishing and boating

- Domestic water supply, for treatment fewer than 575 colonies / $100 \mathrm{~mL}$ fewer than 1000 colonies $/ 100 \mathrm{~mL}$ fewer than 2000 colonies $/ 100 \mathrm{~mL}$.

Suspended solids (mg/L)

\section{- Suspended solids $\leq 30 \mathrm{mg} / \mathrm{L}$}

Interestingly, periods of higher intake of suspended solids (up to $72 \mathrm{mg} / \mathrm{L}$ ) have little effect on the outflow quality, which suggests that the facility has a certain reserve capacity in dealing with suspended solids retention. In fact, sedimentation may prove to be the most problematic aspect of the facility as weekly maintenance by divers and eventual cleaning of the facility are required ${ }^{1}$.

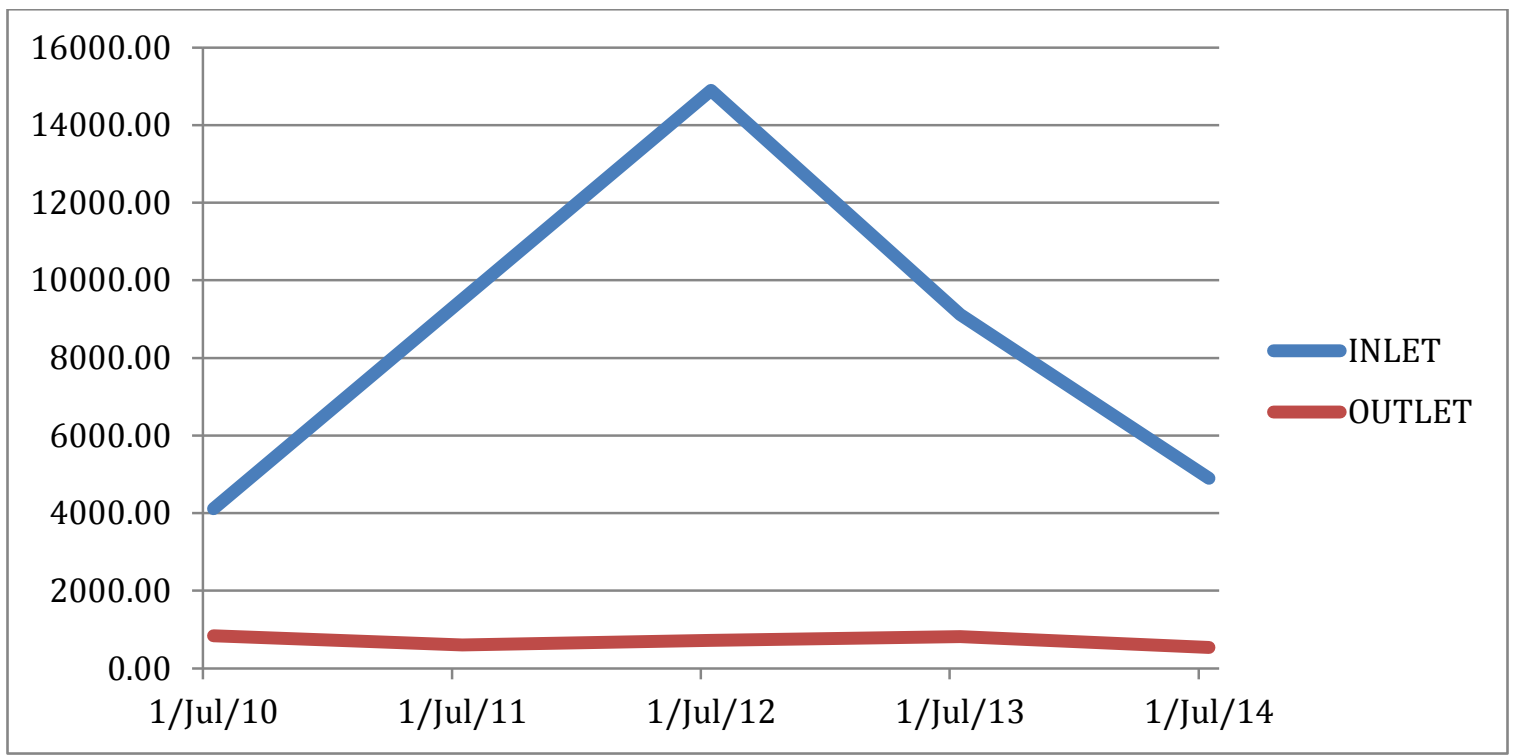

Figure 2. Fecal coliform concentrations (CFU/100 mL), 2010 - 2014 (Data source: Nelson Environmental Inc. 2015. Bio Water Quality Summary Data - May 15, 2015. Appendix A.)

${ }^{1}$ From a conversation with Nelson Environmental Inc. 


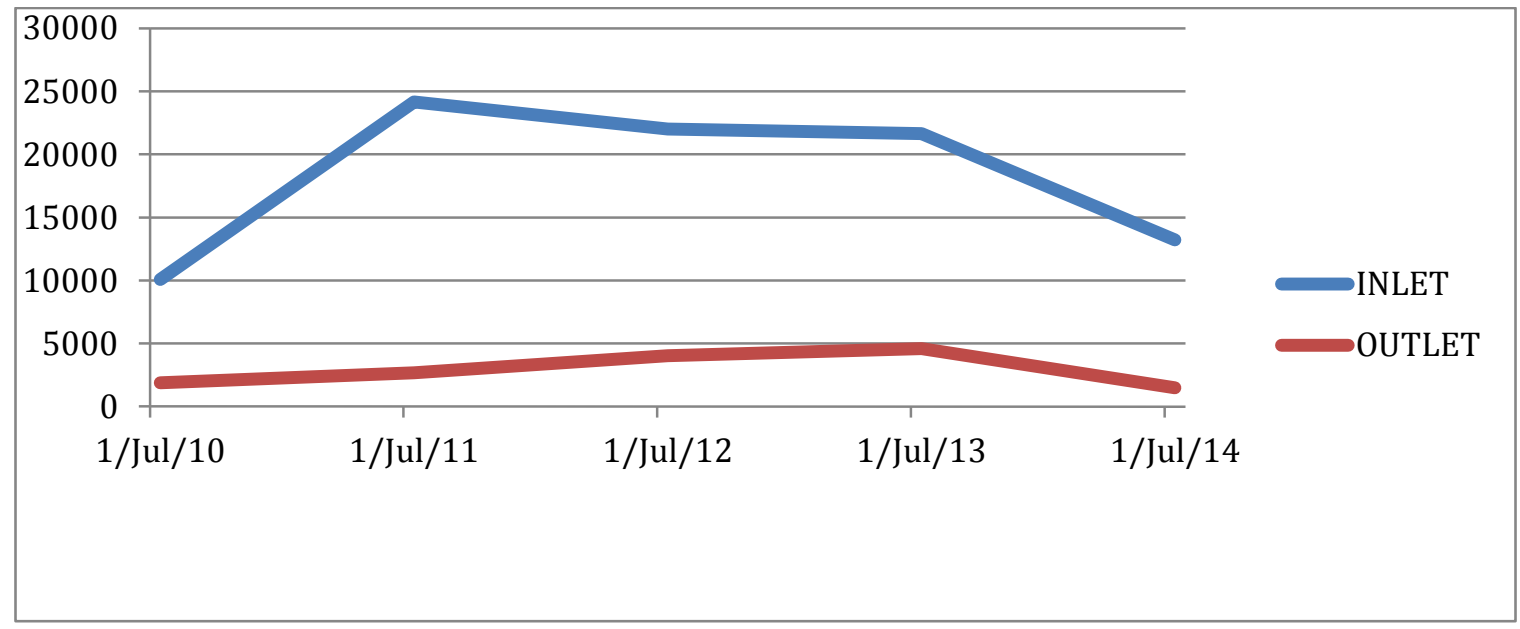

Figure 3. Total coliform concentrations (CFU/100mL) , 2010 - 2015 (Data source: Nelson Environmental Inc. 2015. Bio Water Quality Summary Data - May 15, 2015. Appendix A.)

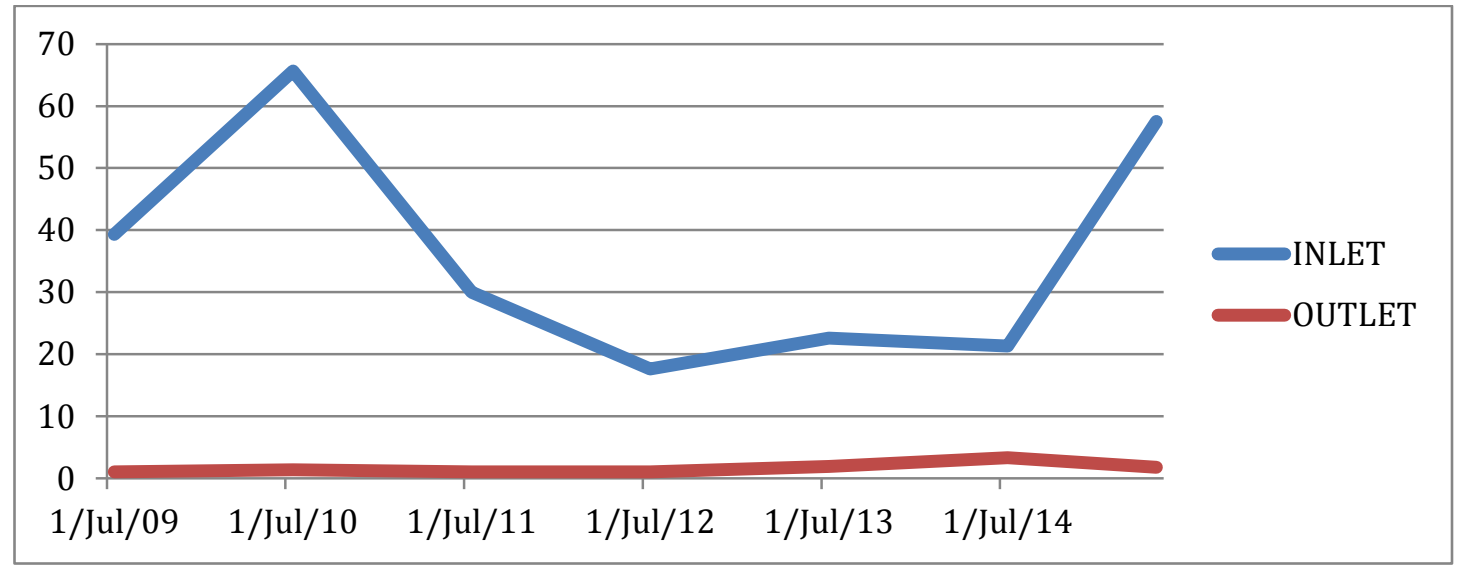

Figure 4. Suspended solids concentration (mg/L) 2009 - 2015 (Data source: Nelson Environmental Inc. 2015. Bio Water Quality Summary Data - May 15, 2015. Appendix A.)

In addition, and as discussed previously, the facility maintains a concentration of dissolved oxygen above $6 \mathrm{mg} / \mathrm{L}$ (see Figure 8), which is considered sufficient for primary and secondary recreational contact (see Figure 7).

Total post-processing phosphorus concentrations fluctuate between 0.07 and $0.61 \mathrm{mg} / \mathrm{L}$, with an average of $0.12 \mathrm{mg} / \mathrm{L}$. Total nitrogen concentrations fluctuate between 17.48 and $28.58 \mathrm{mg} / \mathrm{L}$, with an average of $22.78 \mathrm{mg} / \mathrm{L}$. 


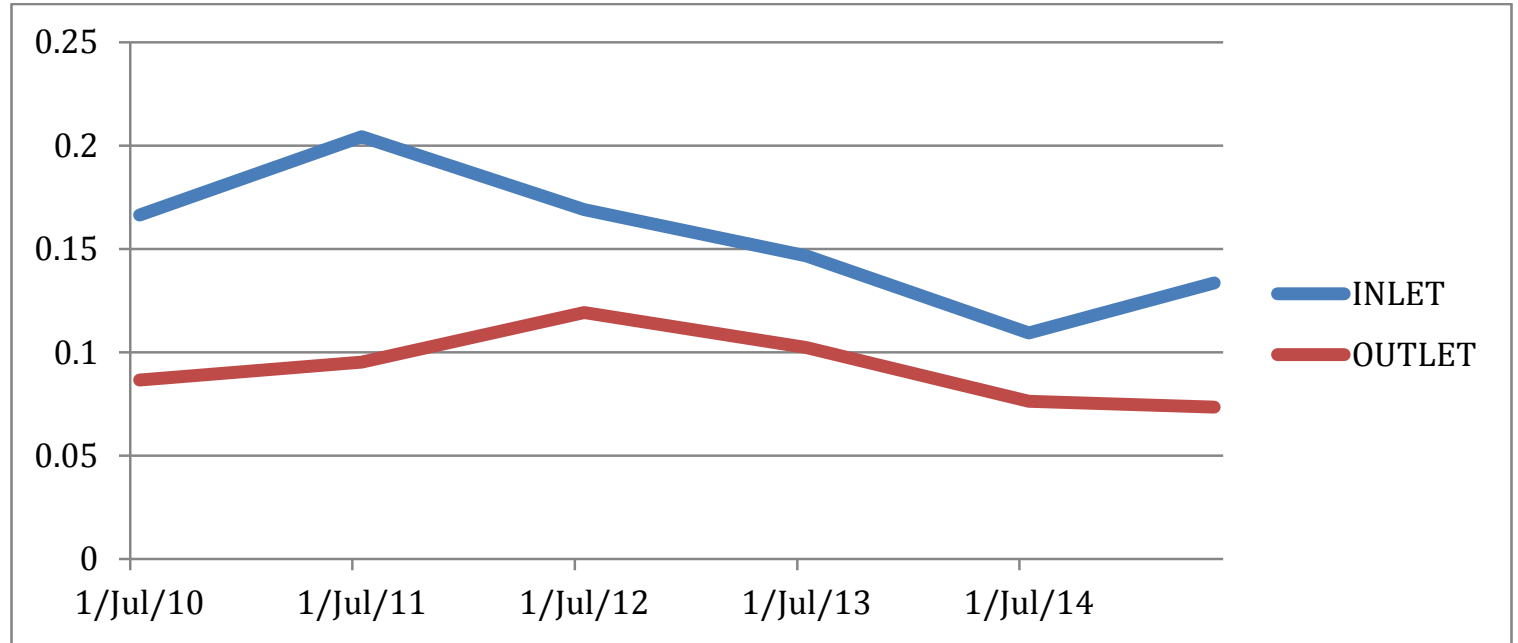

Figure 5. Phosphorus concentrations (mg/L), 2010-2015 (Data source: Nelson Environmental Inc. 2015. Bio Water Quality Summary Data - May 15, 2015. Appendix A.)

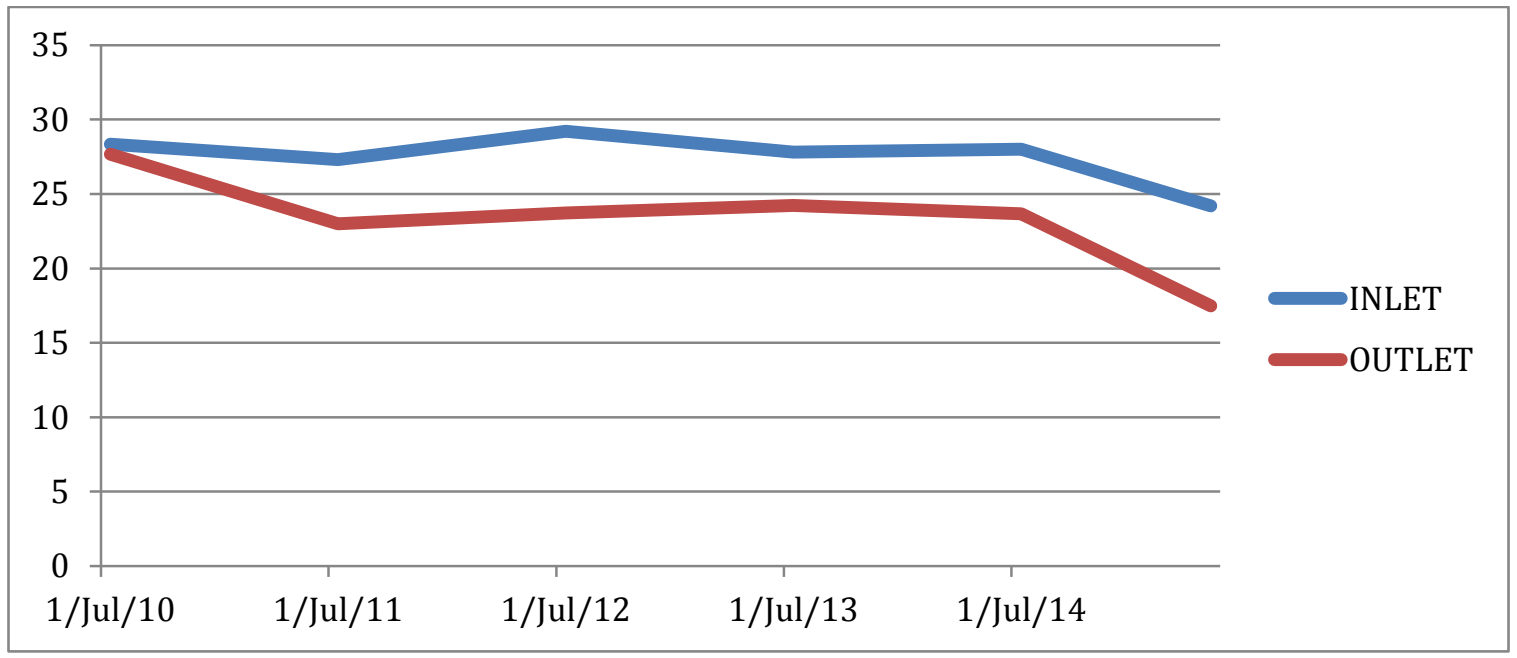

Figure 6. Nitrogen concentrations (mg/L), 2010 -2015 (Data source: Nelson Environmental Inc. 2015. Bio Water Quality Summary Data - May 15, 2015. Appendix A.)

\section{Limitations}

Inlet data for fecal and total coliforms between October 2014 and May 2015 is either not available or unreliable. Averages are thus for the period between July 2010 and July 2014.

\section{- Maintains a concentration of dissolved oxygen above $6 \mathrm{mg} / \mathrm{L}$, which is considered sufficient to maintain healthy aquatic environments.}

\section{Methodology}

The water quality data and preliminary fauna inventory have been obtained from Nelson Environmental Inc. See Figure 10 in Appendix A. 
The facility maintains a concentration of dissolved oxygen above $6 \mathrm{mg} / \mathrm{L}$ (see Figure 8), which is considered sufficient to maintain healthy aquatic environments in warm environments. For example, The North Carolina State University Water Quality Group identifies the following minimum dissolved oxygen concentrations for different environmental conditions and uses:

$\begin{array}{lc}\text { Designated Use } & \text { Mini } \\ \text { Aquatic life } & \\ \text { Warm water fish } & 5.0 \\ \text { Cold water fish } & 6.0 \\ \text { Estuarine biota } & 5.0 \\ \text { Recreational uses } & \\ \text { Primary Contact } & 3.0 \\ \text { Secondary Contact } & 3.0\end{array}$

Figure 7. Lowest acceptable dissolved oxygen levels (mg/l) (Source: Water Quality Group website, University of North Carolina. Accessed August 3, 2015)

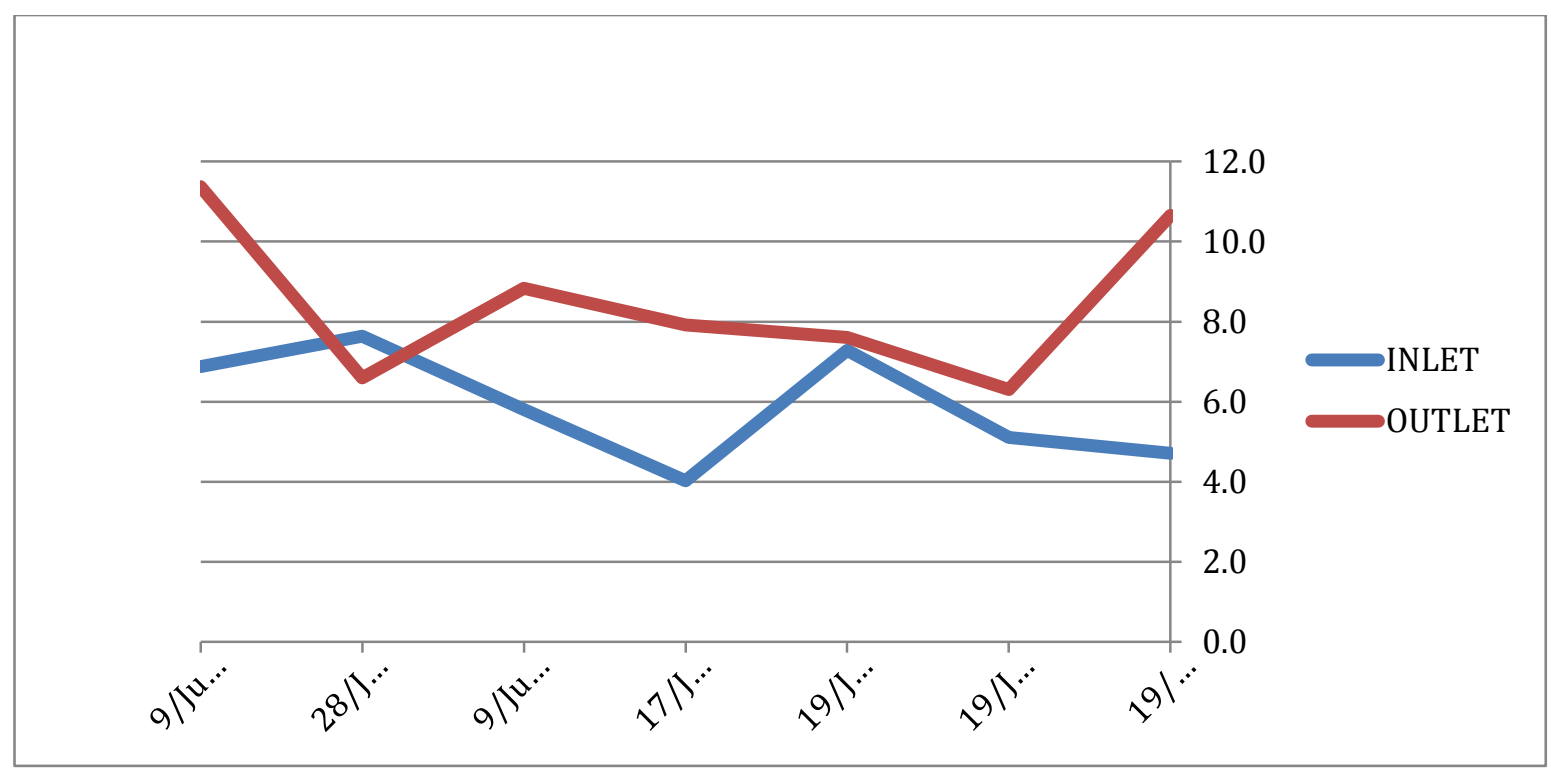

Figure 8. Dissolved oxygen concentrations (mg/L), 2009 - 2015 (Data source: Nelson Environmental Inc. 2015. Bio Water Quality Summary Data - May 15, 2015. Appendix A.)

The bioremediation facility also decreases water turbidity (from 28.9 to $1.5 \mathrm{mg} / \mathrm{L}$ on average) and the amount of present organic carbon (from 5 to $3 \mathrm{mg} / \mathrm{L}$ on average). A slight decrease in $\mathrm{pH}$ (from 7.86 to 8.00 ) and alkalinity (from 204 to $186 \mathrm{mg} / \mathrm{L}$ ) has been noted. The facility has no noticeable impact on water salinity, which remains at an average of $1.74 \mathrm{ppt}$ (Source: Nelson Environmental Inc. 2015. Bio Water Quality Summary Data - May 15, 2015. See Figure 10 in appendix A for a summary.) 


\section{- Supports 15 bird species, 9 fish species, 3 mollusk species, 2 amphibian species, and 3 reptile species as observed on site.}

The improved water quality, together with the newly established 114.9 acres of native plant species, creates a continuous 74.6 mile-long habitat corridor. A preliminary inventory of fauna sightings identifies 15 bird species, 9 fish species, 3 mollusk species, 2 amphibian species, 3 reptile species, and 3 insect species.

\section{$\underline{B i r d s}$}

Bittern, egret, mallard duck, heron, long-beaked bird sp. (unidentified), moorhen, black-winged stilt, woodpecker, eagle, seagull, mynah, house sparrow, spotted dove, pigeon, kingfisher

$\underline{\text { Fish }}$

Tilapia, African jewelfish (cichlid), molly (sailfin \& black-spotted), gambusia (mosquito fish), African and sucker mouth catfish, koi Carp

$\underline{\text { Mollusks }}$

Melanoide snail, ram horn snail, Asian clam

Amphibians

Frog sp., turtle sp.

$\underline{\text { Reptiles }}$

Common house gecko, Arabian spiny-tailed lizard, water snake

$\underline{\text { Insects }}$

Grasshopper, dragonfly, honey bee

Figure 9. Fauna inventory. Nelson Environmental Inc. 2013. Fauna of Wadi Hanifah. Photo Compilation of Fauna Diversity in Wadi (1 ${ }^{\text {st }}$ Edition). May 2009 - September 2013. Report.

\section{$\underline{\text { Limitations }}$}

While water quality samples indicate chemically suitable conditions for riverine and aquatic species, actual fauna and flora inventories remain limited and preliminary. The evidence remains anecdotal and limited to photographic records from the consultant and ADA personnel. Furthermore, many species observed are non-native and / or considered invasive (i.e. the house sparrow, the koi carp) and as such cannot serve as indicators of a healthy ecosystem. 


\section{Social benefits}

- Generates no offensive odors due to an average dissolved oxygen concentration of 6.54 at the facility's outlet.

\section{Methodology}

The water quality data has been obtained from Nelson Environmental Inc. See Figure 10 in appendix A for a summary.

A minimum dissolved oxygen concentration of $1.5 \mathrm{mg} / \mathrm{L}$ is considered the threshold at which odors become imperceptible to human beings ${ }^{2}$. The bioremediation facility maintains an average dissolved oxygen concentration at the outlet of $6.54 \mathrm{mg} / \mathrm{L}$, with a recorded minimum concentration since 2009 of $3.36 \mathrm{mg} / \mathrm{L}$. Within the facility itself (between the main cell groups), dissolved oxygen concentrations average between 8.14 and $8.52 \mathrm{mg} / \mathrm{L}$.

The facility was also designed to promote de-nitrification of nitrogenous compounds to further reduce emanations from the wastewater. Nitrogen concentrations are reduced by $13.53 \%$, with rather low average concentrations of $22.78 \mathrm{mg} / \mathrm{L}$ at the facility outlet.

\section{Economic}

\section{- Saves around $\mathbf{\$ 2 7}$ million per day, the cost of $\mathbf{2 5 3 , 0 0 0}$ barrels of oil that would be required for desalinization and reduces reliance on seawater as a water source.}

253,000 barrels is the amount of water treated by the bioremediation facility made available for recreational and urban functions. The $\$ 27$ million per day is calculated as a loss in revenue on the basis of one barrel of oil required to desalinize 1 barrel of water, and using a 2012 value of $\$ 108$ for a barrel of light crude oil.

\section{$\underline{\text { Sources }}$}

Moriyama \& Teshima Planners Inc. 2010. Wadi Hanifah Restoration Project. March 2010.

Nelson Environmental Inc. 2010. Bioremediation and Surface Water Monitoring Report. February 2010 .

Nelson Environmental Inc. 2013. Fauna of Wadi Hanifah. Photo Compilation of Fauna Diversity in Wadi (1 ${ }^{\text {st }}$ Edition). May 2009 - September 2013. Report.

\footnotetext{
2 According to Nelson Environmental Inc. This concentration is consistent with, or above, the various thresholds suggested in the literature on sewage lagoons for odor control.
} 
Nelson Environmental Inc. 2015. Bio Water Quality Summary Data - May 15, 2015. Appendix A.

Water Quality Group, University of North Carolina.

http://www.water.ncsu.edu/watershedss/info/do.html. Retreived July 20, 2015. 


\section{Appendix A}

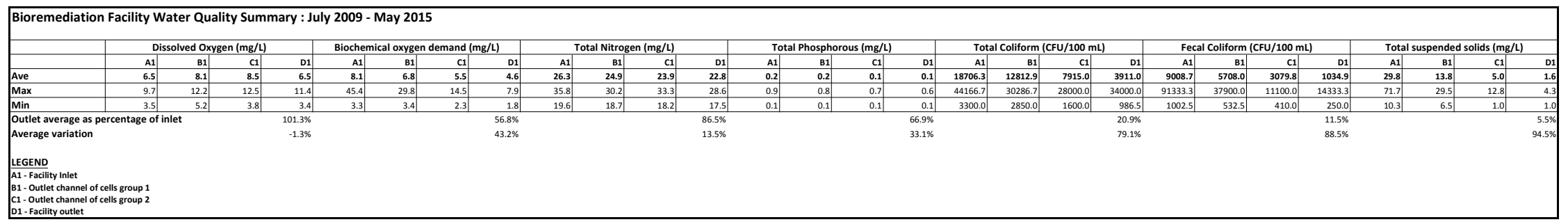

Figure 10. Summary of water quality samples for selected parameters, July 2009 - May 2015. Source: Nelson Environmental Inc. 